\title{
Ingested foreign bodies in children: Do they really pass spontaneously from the gastrointestinal tract? A single-centre experience with 1000 cases
}

\author{
Hasan Özkan Gezer, M.D., (1) Semire Serin Ezer, M.D., (๖) Abdulkerim Temiz, M.D.,

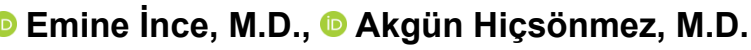

Department of Pediatric Surgery, Başkent University Faculty of Medicine, Adana-Turkey

\begin{abstract}
BACKGROUND: Foreign body (FB) ingestion is frequently encountered in all departments that treat children. FB may bring about significant anxiety for parents and physicians. The present study aims to determine the appropriate approach for FB ingestion in children.

METHODS: The records of 1000 children with a history of FB ingestion between the years 2005 and 2017 were reviewed retrospectively in this study.

RESULTS: Of 1000 children, $53.8 \%$ were male. The most common types of FBs were coins (35\%). X-ray was negative in $49 \%$ of the patients, and $86 \%$ of these patients received no intervention. Of the 504 (5I\%) X-ray-positive patients, the oesophagus (68\%) was the most common location. Life-threatening complications were tracheo-oesophageal fistula (I), Meckel's diverticulum perforation (I), and perforation due to rigid endoscopy (I).

CONCLUSION: We demonstrated that coins, which are the most commonly ingested FBs, have various types and sizes according to their countries of origin, and this affects spontaneous passage. We found that only $48 \%$ (quite low compared to the literature) of the coins passed spontaneously. In asymptomatic patients with a gastric button battery, we suggest a "watchful waiting" approach. The patients should be observed and managed at home. In our study, we found that $85 \%$ of the button batteries that reached the stomach passed spontaneously.
\end{abstract}

Keywords: Battery; coin; foreign body; ingestion.

\section{INTRODUCTION}

Foreign body (FB) ingestion is a common problem among children, with a peak incidence (up to $75 \%$ of the cases) between six months and three years of age. ${ }^{[1-3]}$ The age range of the children and the types of ingested objects are known to vary considerably. Children most frequently swallow coins, toy parts, jewelry or batteries. These patients may have no symptoms, or they may present with severe complications, such as erosions, ulcers or perforations that require emergent medical attention. ${ }^{[3]}$ The majority of ingested FBs (80-90\%) passes spontaneously and causes no further harm, symptoms, or a need for any further intervention. Thus, it is critical to decide whether the patient requires intervention or not. ${ }^{[4-6]}$ Rapid diagnosis and proper management are integral to minimizing any negative outcomes. The indication and timing of interventions are dependent on the type and anatomic location of the FB, as well as the clinical status of the patient. ${ }^{\left[{ }^{[}\right]}$The present study aims to report our experience by presenting patients with suspected foreign body ingestion and reviewing various management options according to the type and location of the foreign body, as determined by a very simple direct X-ray.

\footnotetext{
Cite this article as: Gezer HÖ, Serin Ezer S, Temiz A, İnce E, Hiçsönmez A. Ingested foreign bodies in children: Do they really pass spontaneously from the gastrointestinal tract? A single-centre experience with 1000 cases. Ulus Travma Acil Cerrahi Derg 2020;26:247-254.

Address for correspondence: Hasan Özkan Gezer, M.D.

Başkent Üniversitesi Seyhan Adana Hastanesi, Çocuk Cerrahisi Anabilim Dalı, Seyhan, 0 I 120 Adana, Turkey

Tel: +90 322 - 4586868 E-mail: hozkangezer@yahoo.com.tr

Ulus Travma Acil Cerrahi Derg 2020;26(2):247-254 DOI: 10.14744/tjtes.2019.40350 Submitted: 26.06.2019 Accepted: 18.10.2019 Online: 24.02.2020

Copyright 2020 Turkish Association of Trauma and Emergency Surgery
} 


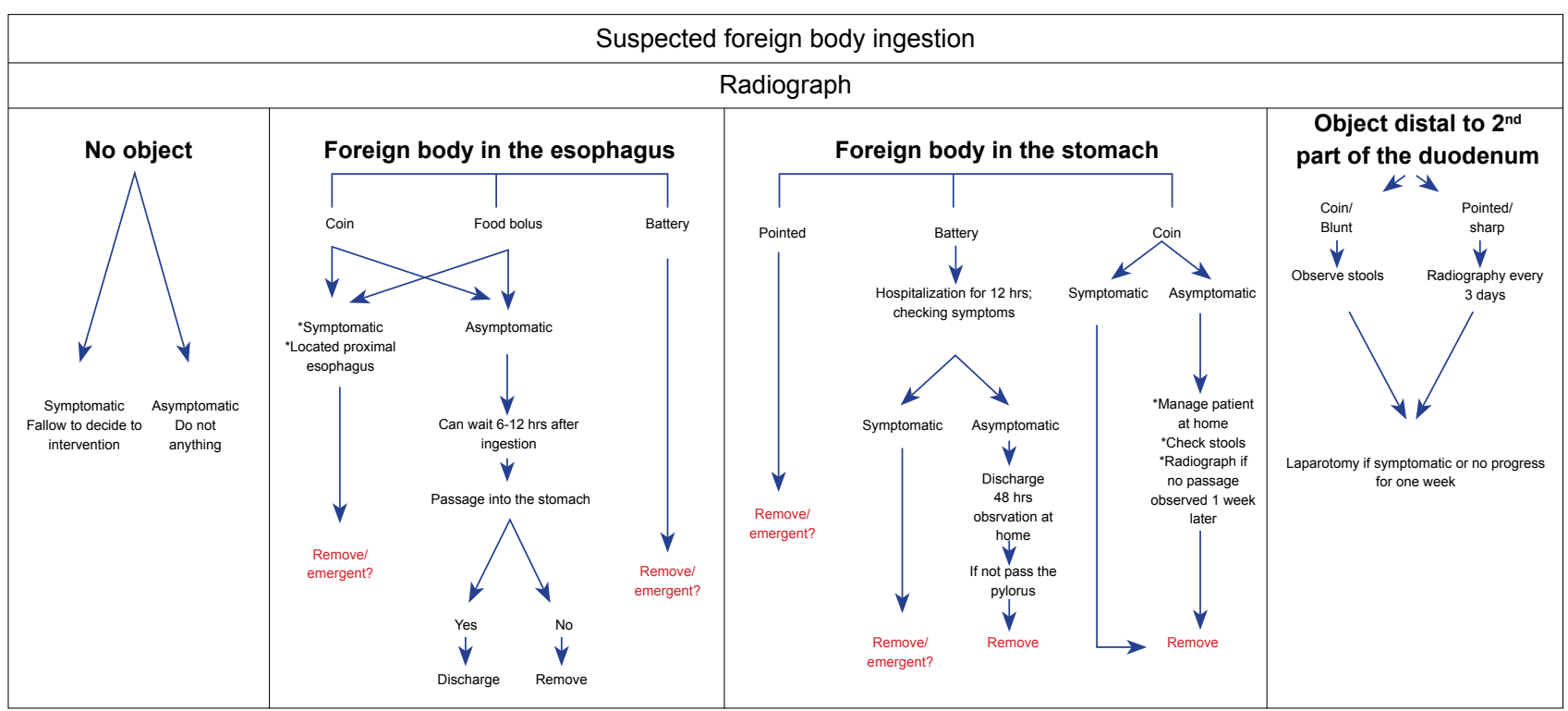

Figure 1. Management protocol of the suspected foreign body ingestion.

\section{MATERIALS AND METHODS}

From November 2005 to June 2017, we retrospectively reviewed the medical records of 1000 children under 18 years old admitted to the hospital with reports of swallowing an FB. We assessed the patients' demographic characteristics (including sex and age), the shape, size and location of the object(s), symptoms, complications, and endoscopic findings when available.

All patients were managed according to a strict protocol, as shown in Figure I.

In all patients, within the first hour of admission, $X$-rays of the neck, chest and abdomen were obtained to determine the location of the $F B$, regardless of the ingestion time and clinical symptoms. If the patient was symptomatic and/or the FB was considered unsafe, they were hospitalized for intervention using a Foley catheter, McGill forceps, or flexible endoscopy by an experienced pediatric surgeon. The Foley catheter was used to "sweep out" coins lodged in the upper oesophagus while the patient was maintained in the Trendelenburg or lateral decubitus position at the emergency clinic, without any sedation or fluoroscopic guidance, by experienced pediatric surgeons. Only three attempts were made to remove the $\mathrm{FB}$; if unsuccessful, no further attempts were made. Additional devices used to remove the FB included a retrieval net basket, snares, rat-toothed and biopsy forceps, and a Roth Net (US Endoscopy Inc., Mentor, OH, USA). After FB removal with endoscopy, a follow-up endoscopy was performed. Aiming to liquefy the oesophageal contents, patients with a food bolus impaction were asked to drink $100 \mathrm{~mL}$ of a carbonated beverage (e.g., Coca-Cola or soda water) every $6 \mathrm{~h}$, in small sips, and always in a sitting position. ${ }^{[1]}$
Statistical analysis was performed using the Statistical Package Program for the Social Sciences 23.0 (SPSS Inc.). Categorical measurements were presented as number and percentage, and continuous measurements were summarised as mean and standard deviation (median and minimum-maximum where needed). This study was conducted in accordance with the Declaration of Helsinki and was approved by the institutional review board of the University Faculty of Medicine.

\section{RESULTS}

During the study period, 1000 children (538 boys and 462 girls) under the suspicion of swallowing foreign bodies were included in this study. The mean age of all patients with suspected FB ingestion was 3.88 years (range, I month to $\mathbf{1 7 . 5}$ years), and the mean age of the patients with proven FB ingestion was three years (range, I month to 17.2 years). The time until admission to hospital was under $4 \mathrm{~h}$ in $69 \%$ of the patients and longer than one week in 5\% (range, 12 min to I 80 days; median, I h). Ninety (0.9\%) patients had come from another city (distance range, 99-II70 km). Thirteen patients who were asymptomatic with no FB detected by X-ray had been referred to us from other cities, with a median distance of $384 \mathrm{~km}$ (range, 100-1200 km) from our city. These patients were discharged at the same night with no planned intervention, treatment or further clinical follow-up.

Patients were divided into five groups according to their ages and FB ingested (Table I). Many kinds of FBs (over 100) were ingested, such as a ball (glass), stone, bead, pen cap, glass fragment, button, buckle, nail, PEG catheter head, piece of meat, tooth and spoon (Fig. 2). The most common types of FBs, identified radiographically or endoscopically were coins (35\%), BBs (19.5\%) and pins (12\%); blue beads attached to an open or closed safety pin, cultural pins, good luck charm pins and turban pins. 
Table I. Ingested FBs according to age and sex

\begin{tabular}{|c|c|c|c|c|c|c|c|c|c|c|c|}
\hline \multicolumn{12}{|c|}{ Age group } \\
\hline & \multicolumn{2}{|c|}{$0-1$} & \multicolumn{2}{|c|}{$I-4$} & \multicolumn{2}{|c|}{$5-9$} & \multicolumn{2}{|c|}{$10-14$} & \multicolumn{2}{|c|}{$\geq 15$} & \multirow[t]{2}{*}{ Totally } \\
\hline & Female & Male & Female & Male & Female & Male & Female & Male & Female & Male & \\
\hline Coin & 2 & 3 & 39 & 62 & 35 & 29 & I & 4 & - & 1 & 176 \\
\hline Battery & 3 & 3 & 35 & 33 & 7 & 17 & - & - & - & - & 98 \\
\hline Safetypin & 10 & 11 & 3 & 7 & 1 & - & - & - & - & - & 32 \\
\hline Turban pin & 4 & 3 & 2 & 2 & 3 & 2 & 9 & 4 & 1 & & 30 \\
\hline Others & 11 & 2 & 30 & 59 & 28 & 15 & 8 & 5 & 6 & 4 & 168 \\
\hline
\end{tabular}

Others: 0-I: charm, meat, fishbone, plastic object, pouch, buckle, earring, nail, spoon, seashell, magnet; I-4: Padlock, bracelet, bead, glass fracture, walnut, laundry latch bow, flower leaf, nail, piece of iron, whistle, button, piece of meat, thread, fishbone, plastic object, earring, mascot, drill bit, bullet, magnet, corn, badge, metal object, jewelry, stone, wire, buckle, screw, bow, ring, staples; 5-9: Blush, ball (glass), stone, bead, pen cap, glass fracture, button, buckle, nail, PEG catheter head, piece of meat, tooth, pepper gas capsule, fishbone, pendant, ring, plum kernel, metal button, magnet, plastic object, badge, clock, lighter stone, stone, chicken piece, wire buckle, screw, staple, foreign material; 10-14: paper clips (open), meat piece, pen tip, bulb, magnet, PEG catheter cap, buckle; 15-16: wire buckle, meat piece, fishbone, spoon.

The most common symptoms were vomiting, dysphagia, sore throat and abdominal pain observed in $12 \%, 8 \%, 3.6 \%$ and $4.8 \%$ of the patients, respectively.

An X-ray examination was performed on all 1000 children admitted. Direct radiography was sufficient for diagnosis in 947 patients. Barium gastrointestinal radiography was used in patients either to demonstrate obstruction related to the FB $(n=16)$ or distinguish the location stomach or colon $(n=20)$.

In 496 (49\%) of the patients, the FBs were not evident in direct radiography. Of these, 379 (76\%) patients were asymptomatic and no other interventions or clinical follow-up were planned. However, 73 of the remaining 120 patients underwent endoscopy due to a suspected FB ingestion and the presence of symptoms upon admission or during the follow-up period, and/ or due to findings on the physical examination. The FB was removed in six patients $(0.05 \%)$, with removal of a button $(n=2)$, bezoar $(n=1)$, piece of food $(n=2)$ and piece of a bag $(n=I)$.

In 504 (5I\%) patients, the FBs were observed via direct radiography.
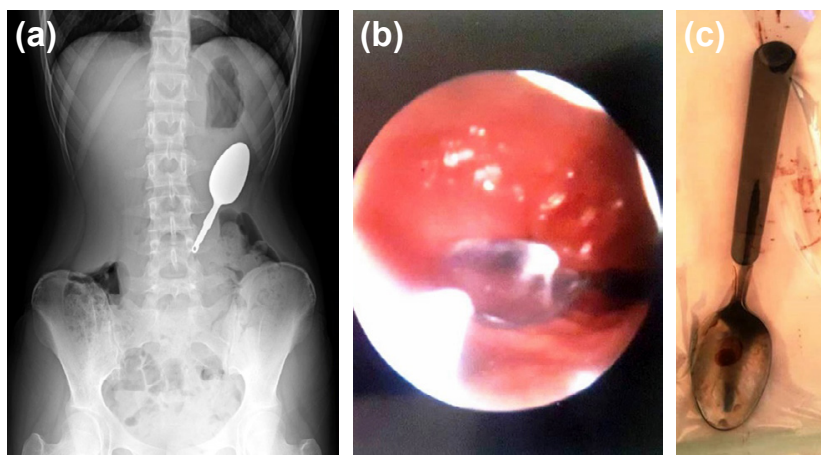

Figure 2. 10-year-old girl ingested spoon (a) x-ray scan (b) endoscopic view (c) removed by laparotomy because endoscopy failed.

\section{Coins}

Of 176 children, FBs were in the oesophagus $(n=56)$, stomach $(n=78)$, small intestine $(n=2 I)$ and colon $(n=2 I)$. Treatment of the patients with coin ingestion is detailed in Figure 3. In one patient, admitted after six months, laparotomy and gastrostomy were needed because endoscopic removal was unsuccessful. Finally, in this study, only $48 \%$ of the ingested coins were able to pass spontaneously. Mild mucosal erosion $(n=2)$ and oesophageal perforation $(n=1)$ were seen. A I.5-year-old boy was referred from another hospital due to perforation. We had learned from his history that a rigid endoscopy was performed within $4 \mathrm{~h}$ to retrieve the coin, which was in the distal oesophagus. However, the oesophagus was perforated during the procedure, and the coin could not be retrieved. After hospitalizing the patient in our facility, emergent endoscopy with removal of the FB was performed, and the patient was treated medically without operation during the 6-week postoperative period.

\section{Button Batteries}

Seventy-six per cent of these patients were under four years of age. In $9 \%$ of the patients (9 of 98 ), the BB was in the oesophagus, and an emergent (within $2 \mathrm{~h}$ ) endoscopy was performed. Variable grade corrosive esophageal burn complication was observed in all patients except two, whose admission time was shorter ( $\leq 2 \mathrm{~h}$ ) (Fig 4). Treatment of the patients with battery ingestion is detailed in Figure 5. Serious BB-related complications were detected in 10\% of the patients, which included tracheo-oesophageal fistula (TEF; $n=I)$, Meckel's diverticulum perforation $(n=l)$ and corrosive burn (at the battery location, i.e. oesophagus, stomach) $(n=8)$. A I.7-year-old girl presented with TEF 25 days after ingestion. She had been admitted to many hospitals, but FB ingestion had not been considered, delaying the diagnosis. After removing the foreign body, she was treated medically for six months. The other serious complication, a Meckel's diver- 


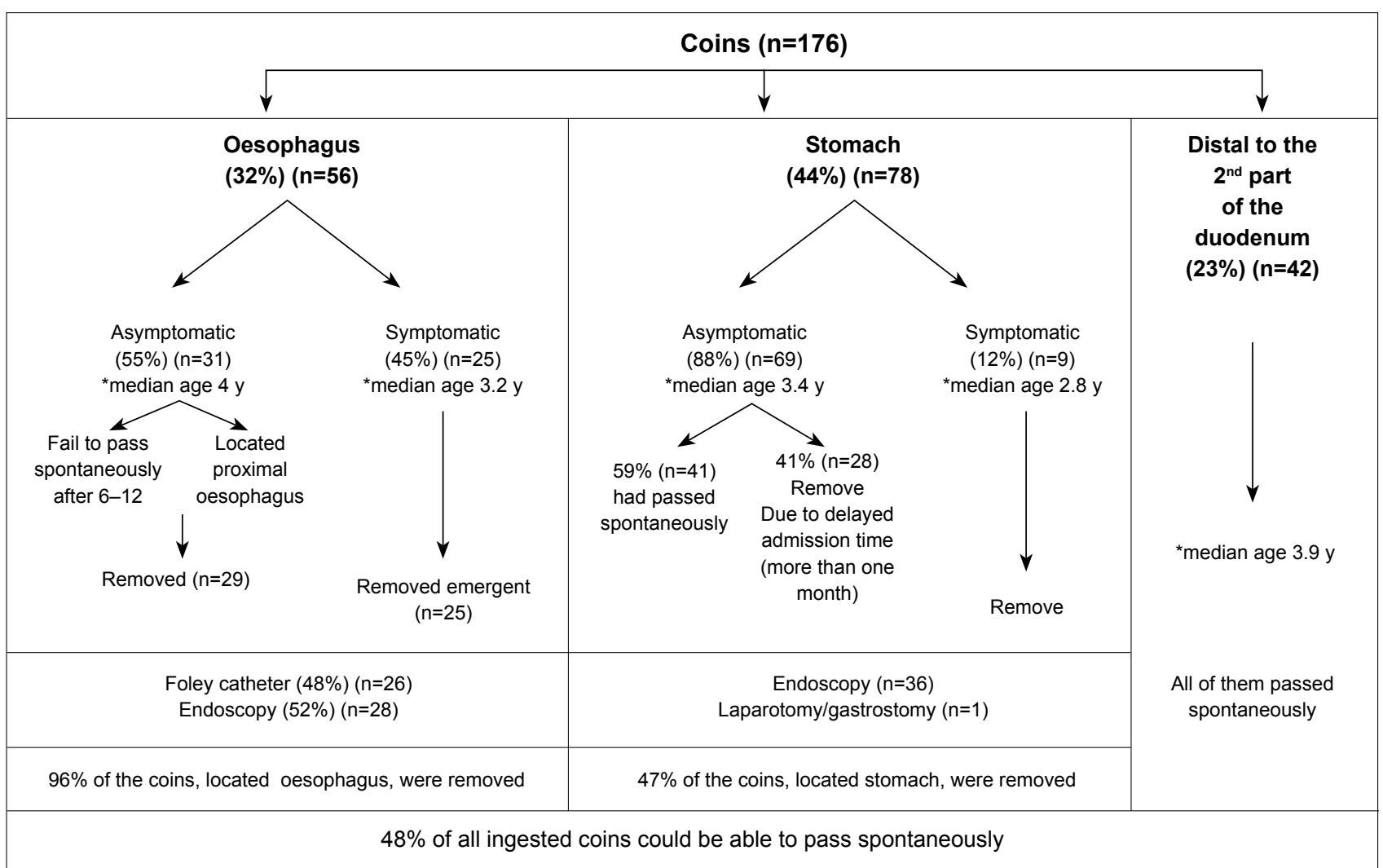

Figure 3. Treatment of the coin ingested patients.
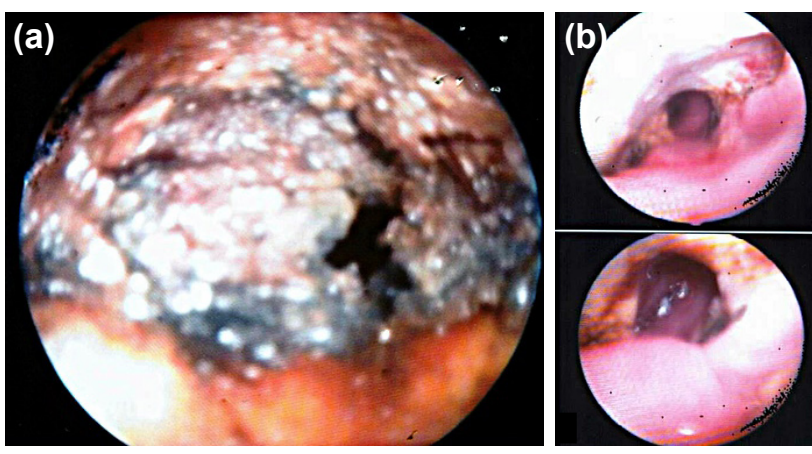

Figure 4. Endoscopic view of the corrosive esophageal burn (a) grade 3b: Extensive necrosis (b) grade 2b: Deep focal or peripheral ulceration.

ticulum perforation, occurred in a I-year-old boy whose admission X-ray showed the FB located beyond the duodenum. $\mathrm{He}$ was discharged and recalled $48 \mathrm{~h}$ later but was admitted to hospital with abdominal pain after $36 \mathrm{~h}$. He was treated with laparotomy and discharged seven days later. Finally, 76\% (75/98) of the ingested batteries were spontaneously and uneventfully eliminated from the gastrointestinal tract.

\section{Safety pins with blue beads and turban pins}

Sixty children ingested one of these, and $65 \%$ were under one year old. An intervention was performed in $28 / 60$ (47\%); this included endoscopy $(n=26)$, McGill forceps $(n=1)$ and laparotomy $(n=1)$. Finally, $53 \%(32 / 60)$ of all swallowed pins were uneventfully passed through the gastrointestinal tract.

\section{Foods}

Seventeen kinds of food, including fish/chicken bones $(n=13)$, fruit seeds $(n=I I)$ and meat $(n=I I)$, had become lodged in the oesophagus of $15 \%$ of the patients in our study. We prefer the endoscopic "push technique" with air insufflations for all.

Of the 504 patients with ingested FBs, 223 (44\%) underwent an intervention, such as the Foley catheter $(n=27)$, McGill forceps $(n=27)$, endoscopy $(n=162)$ or laparotomy $(n=7)$. Interventions in $24 \%$ of the patients were performed without any anaesthesia in the emergency room, and there were no complications. In one patient who had ingested a BB, laparotomy was performed due to a Meckel's diverticulum perforation resulting from tissue necrosis. In four patients, the FB was in the stomach, and laparotomy was conducted to remove the FB following the failure of endoscopic attempts at removal. The characteristics of the other patients are presented in Table 2.

\section{DISCUSSION}

FB ingestion is still a common health problem in the paediatric population. Most ingestions result in only a minor discomfort. [7] It has been reported that $80 \%$ or more of FBs could pass without the need for any intervention in the pre-endoscopic series in the literature. ${ }^{[6]}$ However, according to our criteria, we found percentages that were quite low compared to those in the literature ( $56 \%$ for all ingested FBs, $48 \%$ for coins and $77 \%$ for button batteries). 


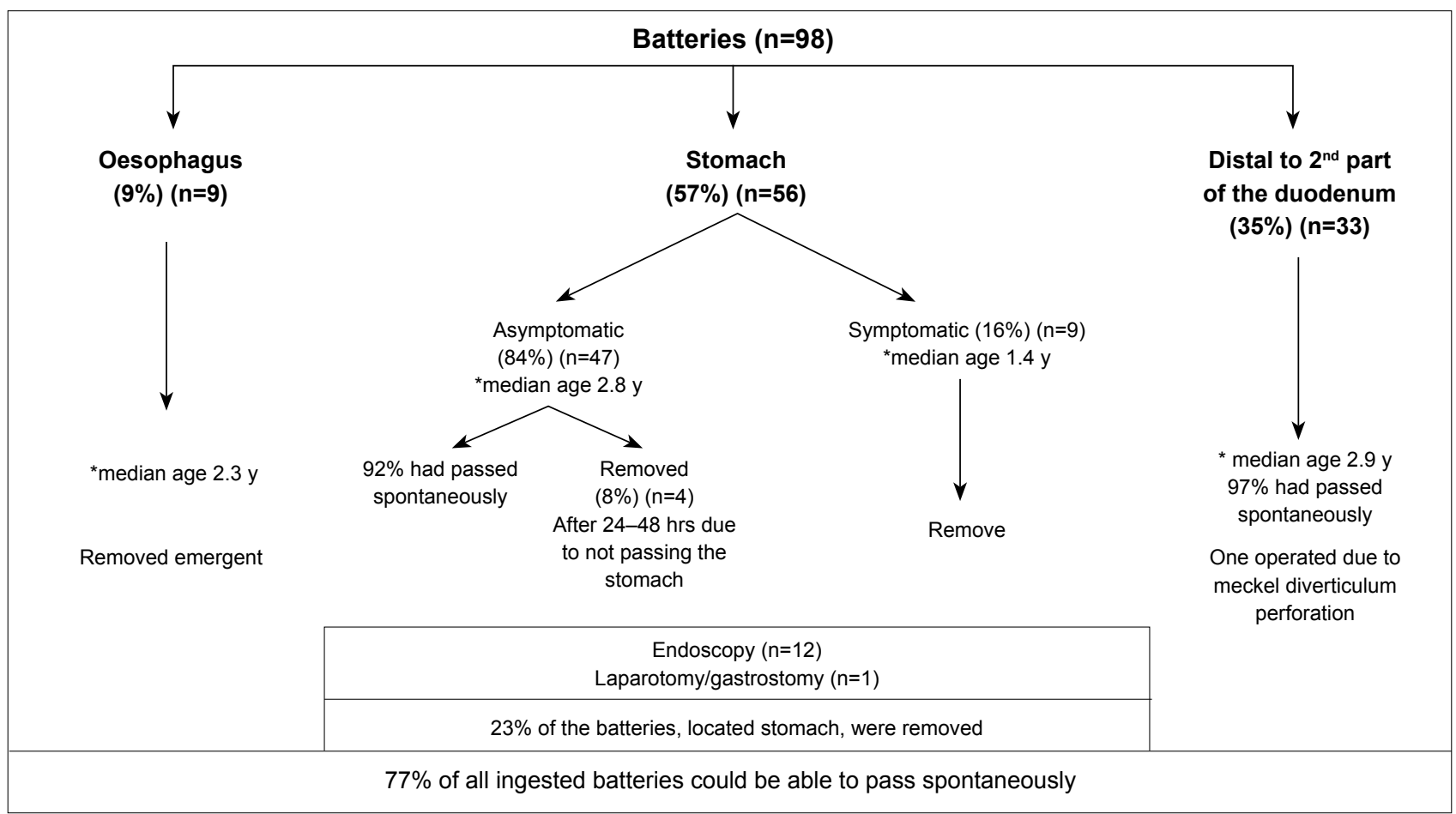

Figure 5. Treatment of the Button Battery ingested patients.

In the management of the FBs, radiographic identification and localisation should be the initial steps. ${ }^{[8]}$ The plain radiograph still appears to be the best method. Additionally, the plain radiograph helps to distinguish the BB from the coin by demonstrating the double halo sign on anteroposterior views and the "step off" sign on lateral views. ${ }^{[9]}$ It is also able to identify complications, such as free air and lung aspiration. ${ }^{\left[{ }^{8]}\right.}$ However, if the patient is unable to provide a satisfactory history, and $\mathrm{X}$-ray studies are negative, then, other diagnostic modalities, such as computed tomography (CT) scanning, contrast examination, handle metal detector (HMD) and diagnostic endoscopy, may be used. Although it has been reported that CT scans without contrast are able to identify FBs in $80 \%$ to $100 \%$ of cases, ${ }^{[5]}$ there are no paediatric studies. ${ }^{[6]}$ A contrast examination should not be performed routinely in the patient with suspected proximal oesophageal obstruction, because of the risk of bronchoaspiration, which may cause severe chemical pneumonitis. Contrast examination should never be used if perforation is suspected. ${ }^{[6]}$ We have not utilised HMD yet, but it has gained popularity in recent years. It has been used for the diagnosis and follow-up of metallic coin FBs only, and it has clear limitations reported: it is not suitable for coins with a depth $>7 \mathrm{~cm}$ from the skin or a low amount of metal. $[10,11]$ Therefore, it can be used only when the parents know that a coin or a coin-like metallic FB was ingested. ${ }^{[12]}$ In the present study, of the 1000 children admitted, an X-ray examination was performed for all patients and was sufficient for diagnosis in 947 patients. Sixty percent of symptomatic patients with a negative X-ray underwent endoscopy for diagnosis, instead of the preferred CT imaging, and $0.05 \%$ required FB removal. Thus, in parallel with the literature, we suggest that an endoscopic evaluation should be performed

Table 2. Patients underwent laparotomy

\begin{tabular}{lccccc}
\hline Age group/sex & FB & $\begin{array}{c}\text { Admission time after } \\
\text { ingestion(hour) }\end{array}$ & Localization & Symptom & Laparotomy indication \\
\hline I0-I4/F & Two pins & 725 & Small intestine & - & Not relocated \\
I-4/F & Battery & 50 & Small intestine & Abdominal pain & Meckel diverticulum perforation \\
I-4/F & Coin & 174 & Stomach & - & Endoscopic removal failed \\
I-4/M & Battery & 52 & Stomach & - & Endoscopic removal failed \\
I0-I4/F & Coin & 168 & Stomach & - & Endoscopic removal failed \\
I0-I4/F & Bezoar & 179 & Stomach & Abdominal pain & Endoscopic removal failed \\
I5-I8/F & Desert spoon & 7 & Stomach & - & Endoscopic removal failed \\
\hline
\end{tabular}

F: Female; M: Male; FB: Foreign body. 
in patients with typical clinical presentations or with a strong suspicion of FB ingestion, even if the radiographic findings are normal. ${ }^{[8]}$

The incidence of FB ingestion and the types of FBs, vary according to the geographic region, culture and patient's age. In the paediatric population, coins are the most common ingested FBs (89\%). ${ }^{[1]}$ In this study, the most common types of FBs were coins (35\%), batteries (19.5\%) and pins (12\%).

In the oesophagus, the most common area of lodgment is at the cricopharyngeus muscle; many authors have generally confirmed that most of these need emergent removal. ${ }^{[1,7]}$ However, there is no consensus concerning objects that have reached the stomach. The decision to remove them depends on many factors, including the patient's age and clinical condition, the size, shape and type of the foreign body, and the technical skill of the endoscopist. ${ }^{[l]}$

\section{Coins}

It is suggested that asymptomatic patients with oesophageal coins can be followed because the coin has a $30 \%$ to $60 \%$ chance of reaching the stomach spontaneously. ${ }^{[6,13,14]}$ Additionally, waiting for 2-4 weeks was suggested in asymptomatic patients with gastric coins, despite there is no specific study in the paediatric patients. ${ }^{[9]}$ However, for the reasons that we listed below, we consider that this period should be one week for the coin in the stomach: I- During the followup period, parents are instructed to monitor the stools for passage of the coin and serial $x$-rays are needed until clearance can be documented. The undesirable effects of observation are increased family anxiety and exposure of children to

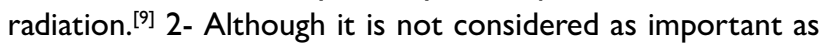
its location and the patient's age in the literature, the size of the coins is $\geq 2.5 \mathrm{~cm}$ in diameter in our country ("I TL", diameter $2.615 \mathrm{~cm}$, thickness $1.95 \mathrm{~mm}){ }^{[13]}$ Our study supports a contrary opinion based on the spontaneous coin passage rates, which were lower for both the oesophagus (4\%) and the stomach (53\%) locations. We attributed this to the age of the patients, most of whom were under four years old and to the size of coins in our country. Besides, in some studies reported in parallel to our study, the findings showed that coins $>23.5 \mathrm{~mm}$, such as the American and Canadian quarters $(24 \mathrm{~mm})$, especially affect children under five years of age. ${ }^{[10]} 3$ - Our high experience in endoscopy. We consider that it is a trouble-free procedure by an experienced specialist and takes about 15 minutes under sedation anaesthesia. 4- We observed in $29 \%$ of the asymptomatic patients with gastric coins that the coins did not pass spontaneously after one month (literature' maximum time limit). Finally, we prefer endoscopic removing of the coin one week later after ingestion. In our study, coin-related complications were seen in three patients as follows: mild mucosal erosion $(n=2)$ and oesophageal perforation $(n=I)$. The perforation was due to a rigid endoscopy performed at another hospital.

\section{Batteries}

One in every $1000 \mathrm{BB}$ ingestion causes serious injury. ${ }^{[7]}$ "External circuit effect due to hydrolysis of tissue fluids" is the most recently identified and popular injury mechanism for BB ingestion. ${ }^{[7,15]}$ Animal models have documented that necrosis within the oesophageal lamina propria may begin as soon as 15 minutes from the time of ingestion, with extension to the outer muscular layer within 30 minutes. ${ }^{[9]}$ Delayed diagnosis is associated with serious complications, such as TEF, oesophageal perforation and oesophageal stricture. As a result, in the cases of delayed treatment, TEF or oesophageal perforation should be ruled out before beginning oral feeding. ${ }^{[6,17]}$ For the presence of a BB in the stomach, the choice between a "watchful waiting" approach or an urgent endoscopic retrieval can pose a dilemma. ${ }^{[18]}$ After the $B B$ passes the pylorus, the risk of splitting decreases. ${ }^{[1]}$ Some authors have suggested that patients younger than six years should be managed at home, with an X-ray to confirm passage in four days, ${ }^{[15]}$ but others have suggested that a BB of diameter $\geq 2 \mathrm{~cm}$ should be removed in younger (under four years) children. ${ }^{[6]}$ Our strategy includes hospitalization of all patients for the first 12 hours for observation. If the patient is asymptomatic and the BB is in the stomach, he or she is managed at home, with a follow-up X-ray in two days to confirm passage. If the BB has failed to pass into the intestine during that time, the child undergoes endoscopic removal. If it has passed the pylorus, the patient is managed at home again until elimination, with an X-ray to confirm passage in 2-4 days. The spontaneous passage should occur in $77 \%$ of gastric BBs and in $76 \%$ of all ingested BBs. Complications, such as a tracheo-oesophageal fistula in a patient examined 25 days after ingestion, were correlated with delayed admission. One patient with a BB located beyond the duodenum suffered a perforation of the Meckel's diverticulum, whereas in $97 \%$, the BB passed spontaneously and uneventfully. Finally, in our study, we found that if the BB had passed through the oesophagus and reached the stomach, $76 / 89$ (85\%) passed spontaneously and uneventfully through the gastrointestinal tract.

Table 3. Timing of the endoscopic removal of the foreign bodies

Emergent (immediate)

- Esophageal obstruction

- Battery in the esophagus

- Sharp-pointed objects in the esophagus

Urgent (within 24 hours)

- Esophageal objects that are not sharp and pointed

- Esophageal food impaction without complete obstruction

- Objects $\geq 6 \mathrm{~cm}$ at or above the duodenum

- Magnets within endoscopic reach 
Pins

Due to unique regional and cultural differences, pins were the third most commonly swallowed FB. In our country, it is widely believed that a blue bead, typically attached to a baby's clothing with a safety pin, protects small children from evil. Babies may swallow the blue beads with or without the safety pin. Additionally, turban pin ingestion was seen at every age due to either the patients or their parents covering their heads. ${ }^{[19]}$ In our study, an endoscopy was performed in $71 \%$ $(23 / 32)$ of the patients who ingested an open safety pin. This intervention was also performed for turban pins, although at a lower rate of $20 \%$, as the patients were older, and the FBs passed spontaneously. Finally, 53\% (32/60) of the pins that had reached the stomach was able to spontaneously pass through the gastrointestinal tract.

There have been several methods described in the literature for removing an FB from the oesophagus, including McGill forceps, rigid and flexible oesophagoscopy, Foley catheters, oesophageal bougienage and open surgery. ${ }^{[20]}$ Endoscopy is predominantly used as a surgical technique, and a Foley catheter is mostly preferred as a non-surgical technique, in which a deflated catheter is passed beyond the FB, inflated and removed under fluoroscopy. ${ }^{[1]}$ However, we know that Foley catheter effectiveness is greatly operator-dependent, and this has led to concerns about perforation, aspiration and acute airway obstruction if performed incorrectly. In our study, there were no complications concerning Foley catheter use. Additionally, when we have the slightest suspicion that a FB can be a BB, we do not use the Foley catheter. Endoscopic removal is suggested for gastric FBs if they are sharp, long ( $\geq 4-5 \mathrm{~cm}$ for infants and young children, $\geq 6-10 \mathrm{~cm}$ for older children), or wide ( $\geq 2 \mathrm{~cm}$ in diameter for infants and young children, $\geq 2.5 \mathrm{~cm}$ in diameter for older children). Additionally, if the patient has a larger BB $(\geq 2 \mathrm{~cm})$, a BB which has remained in the stomach for over 48 hours, multiple magnets, or gastric retention of any objects for more than 3-4 weeks, endoscopic removal is also recommended. ${ }^{[3]}$ The timing of the intervention was divided into three groups: emergent, urgent, and non-urgent. ${ }^{[8]}$ Patients with proximal oesophageal obstruction and patients who have ingested BBs or long and sharp-pointed objects need emergent (immediate) intervention, ${ }^{[5]}$ as presented in Table 3.

The main limitations of our study are the differences in the incidence and types of FBs based on the geographic region, culture and age of the patients, in addition to the retrospective nature of this study.

\section{Conclusion}

At presentation, the physician can use a simple $X$-ray to determine the type and location of the ingested $F B$, and whether the patient requires immediate endoscopic intervention or can simply be observed on an outpatient basis. In our study, we clearly demonstrated two principles as follows. First, coins - the most commonly ingested FBs - have various types and sizes according to their countries of origin, and we believe that the type and size of the coin and the patient's age are more important for the spontaneous passage from the gastrointestinal tract. In our study, only $48 \%$ of all ingested coins passed spontaneously. Second, for a BB located in the stomach, we suggest a "watchful waiting" approach rather than an endoscopic retrieval. These patients should be observed and managed at home, with an X-ray to confirm passage two days after ingestion. In our study, we found that when BBs had passed through the oesophagus and reached the stomach, $85 \%$ passed spontaneously and uneventfully through the gastrointestinal tract.

Ethics Committee Approval: The study protocol was approved by the Başkent University Faculty of Medicine Ethics committee.

Peer-review: Internally peer-reviewed.

Authorship Contributions: Concept: H.Ö.G.; Design: H.Ö.G.; Supervision: S.S.E.; Fundings: E.I.; Materials: H.Ö.G.; Data: E.I.; Analysis: A.T.; Literature search: H.Ö.G.; Writing: H.Ö.G.; Critical revision: A.H.

Conflict of Interest: None declared.

Financial Disclosure: The autors declared that this study has received no financial support.

\section{REFERENCES}

1. Antoniou D, Christopoulos-Geroulanos G. Management of foreign body ingestion and food bolus impaction in children: a retrospective analysis of 675 cases. Turk J Pediatr 2011;53:381-7.

2. McNeill MB, Sperry SL, Crockett SD, Miller CB, Shaheen NJ, Dellon ES. Epidemiology and management of oesophageal coin impaction in children. Dig Liver Dis 2012;44:482-6. [CrossRef]

3. Lee JH, Lee JH, Shim JO, Lee JH, Eun BL, Yoo KH. Foreign Body Ingestion in Children: Should Button Batteries in the Stomach Be Urgently Removed?. Pediatr Gastroenterol Hepatol Nutr 2016;19:20-8. [CrossRef]

4. Wu W, Lv Z, Xu W, Liu J, Sheng Q. An analysis of foreign body ingestion treatment below the pylorus in children. Medicine (Baltimore) 2017;96:e8095. [CrossRef]

5. Bekkerman M, Sachdev AH, Andrade J, Twersky Y, Iqbal S. Endoscopic Management of Foreign Bodies in the Gastrointestinal Tract: A Review of the Literature. Gastroenterol Res Pract 2016;2016:8520767. [CrossRef]

6. Thomson M, Tringali A, Dumonceau JM, Tavares M, Tabbers MM, Furlano R, et al. Paediatric Gastrointestinal Endoscopy: European Society for Paediatric Gastroenterology Hepatology and Nutrition and European Society of Gastrointestinal Endoscopy Guidelines. J Pediatr Gastroenterol Nutr 2017;64:133-53. [CrossRef]

7. Chinski A, Foltran F, Gregori D, Ballali S, Passali D, Bellussi L. Foreign Bodies in the Oesophagus: The Experience of the Buenos Aires Paediatric ORL Clinic. Int J Pediatr 2010;2010:490691. [CrossRef]

8. Hong KH, Kim YJ, Kim JH, Chun SW, Kim HM, Cho JH. Risk factors for complications associated with upper gastrointestinal foreign bodies. World J Gastroenterol 2015;21:8125-31. [CrossRef]

9. Kramer RE, Lerner DG, Lin T, Manfredi M, Shah M, Stephen TC, et al; North American Society for Pediatric Gastroenterology, Hepatology, and Nutrition Endoscopy Committee. Management of ingested foreign 
bodies in children: a clinical report of the NASPGHAN Endoscopy Committee. J Pediatr Gastroenterol Nutr 2015;60:562-74. [CrossRef]

10. Nation J, Jiang W. The utility of a handheld metal detector in detection and localization of pediatric metallic foreign body ingestion. Int J Pediatr Otorhinolaryngol 2017;92:1-6. [CrossRef]

11. Aljasser A, Elmaraghy CA, Jatana KR. Utilization of a handheld metal detector protocol to reduce radiation exposure in pediatric patients with esophageal coins. Int J Pediatr Otorhinolaryngol 2018;112:104-8. [CrossRef]

12. Hamzah HB, James V, Manickam S, Ganapathy S. Handheld Metal Detector for Metallic Foreign Body Ingestion in Pediatric Emergency. Indian J Pediatr 2018;85:618-24. [CrossRef]

13. Waltzman ML, Baskin M, Wypij D, Mooney D, Jones D, Fleisher G. A randomized clinical trial of the management of esophageal coins in children. Pediatrics 2005;116:614-19. [CrossRef]

14. Caravati EM, Bennett DL, McElwee NE. Pediatric coin ingestion. A prospective study on the utility of routine roentgenograms. Am J Dis Child 1989;143:549-51. [CrossRef]
15. Litovitz T, Whitaker N, Clark L, White NC, Marsolek M. Emerging battery-ingestion hazard: clinical implications. Pediatrics 2010;125:116877. [CrossRef]

16. Yalçin S, Karnak I, Ciftci AO, Senocak ME, Tanyel FC, Büyükpamukçu N. Foreign body ingestion in children: an analysis of pediatric surgical practice. Pediatr Surg Int 2007;23:755-61. [CrossRef]

17. Kimball SJ, Park AH, Rollins MD 2nd, Grimmer JF, Muntz H. A review of esophageal disc battery ingestions and a protocol for management. Arch Otolaryngol Head Neck Surg 2010;136:866-71. [CrossRef]

18. Lin CH, Chen AC, Tsai JD, Wei SH, Hsueh KC, Lin WC. Endoscopic removal of foreign bodies in children. Kaohsiung J Med Sci 2007;23:447-52.

19. Aydoğdu S, Arikan C, Cakir M, Baran M, Yüksekkaya HA, Saz UE, et al. Foreign body ingestion in Turkish children. Turk J Pediatr 2009;51:127-32.

20. Jayachandra S, Eslick GD. A systematic review of paediatric foreign body ingestion: presentation, complications, and management. Int J Pediatr Otorhinolaryngol 2013;77:311-7. [CrossRef]

\section{ORIJIINAL ÇALIŞMA - ÖZET}

\section{Çocuklarda yutulan yabancı cisimler: Gerçekten gastrointestinal sistemden kendiliğinden geçiyorlar mı? 1000 olgu ile tek merkezli deneyim \\ Dr. Hasan Özkan Gezer, Dr. Semire Serin Ezer, Dr. Abdulkerim Temiz, Dr. Emine İnce, Dr. Akgün Hiçsönmez}

Başkent Üniversitesi Tıp Fakültesi, Çocuk Cerrahisi Anabilim Dalı, Adana

AMAÇ: Yabancı cisim (YC) yutulması, çocukları tedavi eden tüm kliniklerde sıkça karşılaşılan bir durumdur. Ebeveynler ve doktorlar için önemli kaygılara neden olmaktadır. Amacımız YC yutan çocuklarda en uygun yaklaşımı belirlemekti.

GEREÇ VE YÖNTEM: 2005-2017 yılları arasında YC yutulması ile başvuran 1000 çocuğun kayıtları geriye dönük olarak incelendi.

BULGULAR: Bin çocuğun \%53.8'i erkekti. En sık görülen YC tipi madeni paraydı (\%35). Hastaların \%49'unda direkt grafide YC görülmedi ve bu hastaların \%86'sına herhangi bir müdahale yapılmadı. Beş yüz dört (\%5I) X-ray pozitif olan hastada, özofagus (\%68) en yaygın yerleşim yeriydi. Hayatı tehdit eden komplikasyonlar trakeoözofageal fistül (I), Meckel divertikül perforasyonu (I) ve rijit endoskopiye bağlı perforasyon (I) idi.

TARTIŞMA: En fazla yutulan YC'lerden olan madeni paranın şekil ve büyüklüklerinin ülkelere göre değiştiğini ortaya koyduk ve bunun da kendiliğinden geçiş sonuçlarımızı etkilediğini gördük. Madeni paranın kendiliğinden gastrointestinal sistemi terk etme oranını literatüre göre oldukça düşük, \%48 olarak bulduk. Düğme (saat) pili yutup midesine geçmiş, semptomsuz hastalarda ise, "acil endoskopik çıkarım” değil, "dikkatli/yakın takip" yaklaşımı öneriyoruz. Hastalar evde izlenmeli ve yönetilmelidir. Çalışmamızda, pilin mideye ulaşması durumunda, \%85'inin gastrointestinal sistemden kendiliğinden ve sorunsuzca geçtiğini belirledik.

Anahtar sözcükler: Madeni para; pil; yabancı cisim; yutma.

Ulus Travma Acil Cerrahi Derg 2020;26(2):247-254 doi: 10.14744/tjtes.2019.40350 